\title{
正方形中空スラブのせん断破壞に関する害験的研究 EXPERIMENTAL STUDY ON SHEAR FAILURE OF THE SQUARE HOLLOW SLABS
}

\author{
藤本敬之* \\ Takayuki FUJIMOTO
}

\begin{abstract}
The shear strength and shear failure phenomena were investigated for the square hollow slabs with partial lateral restraint at all edges. The experiments were done by testing three series of the slabs which had been shear-reinforced by H shaped steel and $r$ ing shaped steel. The test results concerning to shear strength and failure phenomena were discussed with the analizing results for an equivalent cross beam structure model. The load-deflection relationship was also discussed with the flexural analizing results with consideration to compressive membrane actions.
\end{abstract}

Keywords: hollow slab,shear failure, reinforced concrete,shear strength,membrane force, cross beam 中空スラフ，せん断破壊，鉄筋コンクリート，せん断強度、面内压縮力，格子梁

1. 序

大スパン床組を構築するために，スラブ断面の中央部 に円管を埋め込み，自重の軽量化を計っている鉄筋コン クリートや空床スラブは，何重をできるだけ均等に周り の支持部へ伝達するように，スラブ内の位置によって， 円管の配列方向の向きを変えるなとの方法が考案されて いる。

ここでは先ず本報告の意義を明らかにするために，中 些スラブの研究と実用化の厢史の流れを略述し，次に， 本報告の骨子を述べる。

1962年に，松茾が建築物の床に使用した一方向性中空 スラブについて，施工方法と实施設計例，および単純梁 形式の曲げせん断奏験と水平せん断实験の結果を報告し たのが，中空スラブの研究と実用化の始まりである。

1965年には，F.Simon＇２が正方形および矩形中空ス ラブ周辺の支持部への荷重伝達が効率良く行われるよう に，円管配列方向の向きを，スラブの位固によって畒え た二方向㭫中空スラブの設計方法を発表して，その普及 に貢献した。

1980年に，松井らが、円管力向をスパン二方向に配置

した，矩形中空スラブの実施設計と，その静的載荷曲 げ契験について垟告している。さらに，前記した F.Si monsと同じように，円管方向をスラブ位置によって変え た二方向性中空スラブついて，曲げ破壊寒験例を拜告し ている。

また，入江ら注円管をスパン一方向に配置し，周边部 を拘束した二方向性中空スラブを用いて，スラフ中央に 集中載荷した奏験結果について報告している。

以上，中空スラフの現在に至る璴史的な流れは，曲げ 実験による解析が主で，せん断実験例は少ない。特に， 前記した中空孔をスパン一方向に配置し，周迅部を拘束 した二方向性中栄スラブのせん断解析は，ほとんと行わ れておらず,これからの研究と言った状況にある。また， スラブの耐力や，変形性状に大きな影響を与えるスラフ 周辺の拘束条件を考慮した解析も，今後に残された課題 となっている。

このような糜史的背景と、コンクリートという脆性の 強い材筫に加え，せん断破塤を起こし易い断面を有して いる中空スラブのせん断破阹に対する実験データーの集 積とその解析は，是非とも，積み上げて行かねばならぬ

\footnotetext{
* 近畿大学、学部建築学科 助教授. 工博

Assoc. Prof., Dept. of Architecture, Faculty of Engineering, Kinki Univ., Dr. Eng.
} 
問題であろうと考える。斯粎な観点から本報告では，ス ラブ周辺を拘束したスパン一方に円筒形の中空孔を持 つ, 二方向性正方形中空スラブを対象に行ったせん断破 壊実験結果と，その解析結果について報告することとす る。

この中空スラブは前述の通り, 此較的せん断破塔を起 こし易く，複雑なせん断破壊形状を示すものであった。 このような現象の把握のために，実験によるせん断破壊 の挙動と形状を示し, さらに, 数值解析においては, 中 空スラブを簡単なモデルに置換して取り扱う方が, 破坮 形状や耐力を捉え易いと考え, 格子梁構造にモテル化し て, せん断と曲げ解析を行い，その解析結果の妥当性を 尖験結果と比較して論じた。

本報告中の, 中空方向に植角な方向のせん断破塤につ いては, 文献 7)で，曲げ酎力やその変形については， 文献 8）で既に論じている。

尚, 本報告は，すでに年頭発表したものを，一部修正

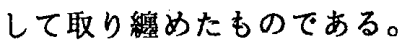

\section{2. 実験概要}

実験用試験体の種別は，シリーズ 1，2，3からなって いる。シリーズ 1では, せん断補强材として, 中空孔間 のウエブ部分にH形の鎆（以後H形と称す）を施した試 験体の実験により，せん断破壊状熊を観察した。さらに，

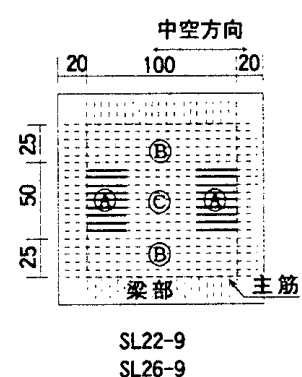

(a)

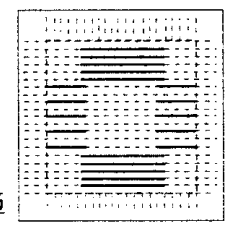

STL22-5 STL26-5

(b)

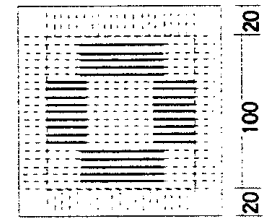

STL22-9 单位CD STL26-9
図一 1 せん断補強の配置と試験体名

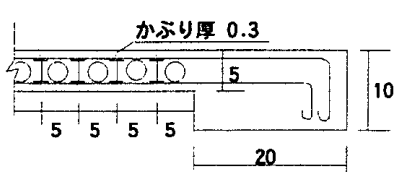

(a) $シ y-\pi \cdot 10$ 睹面

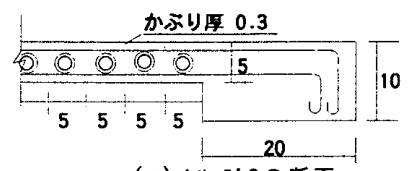

(c) 沙

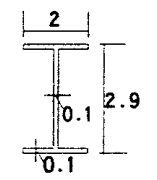

（b）H形の桷の断面と寸法 かふり厚 0.3

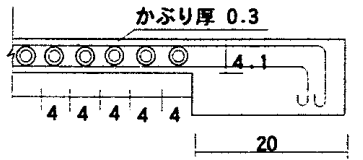

(d) 沙 $-\pi \cdot 3$ 断面

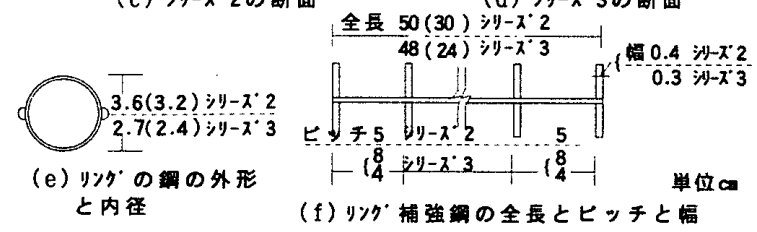

図一－2試験体断面と補强の形と寸法
その結果を踏まえて，シリーズ 2,3では，H形よりせん 断補強効果をより期待し得るリングの鎆（以後リンクと 称す）を，中空孔の周辺に施して，試験体の曲け破壊へ の指向性を強めるよう計西した。

図ー5 シーリズ 1に、“補強なし”型として、このシ リースとは別に，せん断補強を施していない試験体の破 壊図を挴げて, 以下に示す，せん断補強方法の根拠を説 明することとする。

“補強なし”武験体の破壊は，早期に中空方向の端部 でせん断破壊する一方向性傾向の強いものであった。こ の破壊は，中空方向のスラブ中央部両脇（図-1（a）の B部分）において，中空方向に直角な方向で最初のせん 断破壊を生じ，荷重の再配分の結果，中空方向に荷重 増を来して，この方向の端部（図一1（a）(®部分）が破 壊したものであろう。

この判断の根掩は, 中空方向に直角な方向で，極めて せん断破壊し易いことど, 带板状の長手方向に中空孔を 配膡した中空スラブが, 曲げ破壊であったこととにもと ずいている。

この”補強なし”型の破壊にもとずいて，中空スラフ のせん断䩂力の增強を計り，せん断破塤機構をも明らか にしょうとして，図-1（a），（b），（c）の3種類の せん断補強パターンを計画した。（a）は，最終的破壊 を起こすと考える中空方向の®部分に，せん断補強を施 したものであり，（b），（c）では，(B)部分のせん断補 強が，如何にせん断耐力の増加をもたらすかを，(部分 のせん断補強量の変化と関連させて捉えようとしたもの である。

先ず、シリーズ ににおいては，せん断補強に H形を使 用している。この補強によって，せん断補強奻果が期待 出来，早期のせん断破壊を防ぎ得ると考えたためである。 さらに、シリーズ 2と3においては，䀐の代わりに， 中䇥孔周辺にリングを施して、よりせん断補強好果を高 め，曲け破壊へと近すくように計画した。

これら中空スラフ試験体の内法スパンは，全て 1mx1m の正方形で, その周りに, 縦 $10 \mathrm{~cm}$, 横 $20 \mathrm{~cm}$ 断面の梁 を設けて一体打ちとした。シリーズ 1は，図ー2（a）に 示すように，スラブ厚設計值を $5 \mathrm{~cm}$ とし，中空孔（值径 26西）を，全断面にわたって一方向に $5 \mathrm{~cm}$ 間隄に設け ている。これら中空孔間のウエブには, 同図に示す 形をせん断補強に用いている。シリーズ 2 は、図-2(c) に挃げたように、シリーズ 1と同一スラブ厚断面に中 空れ（直径22，26m）を設け、リングをその周辺に施し てせん断補強に用いている。シリーズ 3は，図ー2（d) に示すように，スラフ厚設計值を $4.1 \mathrm{~cm}$ とし，中空れ （直径 $18 \mathrm{~mm}$ ）を $4 \mathrm{~cm}$ 間淂に，全断面にわたって設けて， シリーズー2と同様，せん断補强にリングを使用してい 
る。これらシリーズ 1，2，3において，シリーズ 1にの み同一の試験体を 2体用いている。

H形の断面寸法は図一2（b）に，また，リングの直径 を图一2（e）に示す。（）内はリングの内径である。リ ングの全長とピッチと幅を図ー2（f）に示す。全長の大 きな数字が(B)部分の寸法であり，（）内の小さな数字が (A)部分の寸法である。シリーズ 3では, リングの数を 2 倍にしたせん断補強をも使用している。

H形およびリングの配置は，シリーズ $1 ， 2$ み, 図一 1に試験体名と共に示し，その配置を以下に説明する。

(A)部分のみを補強する同図 (a) を SL型, (A) 部分と(B) 部分を補強する (b)，（c）四をSTL型と名付ける。SL 型補強鋼の配置は，シリーズ 1 ，2の場合は 9 本，シリ 一ズ 3の場合は6本である。STL型補強鋼の配置では, シリーズ 1，2の場合，(A)部分に5本と 9本の2種類と して，B部分には，2種類とも5本配置している。シリ ーズ 3では, (A)部分に 6本と 12本の 2種類として, B 部分には，2種類とも 6本配置している。さらに，シリ ーズ 3のみに, リングの数を 2倍にした試験体を加えて いる。

試験体名は，H形およびリングの配置の形を表す SL,

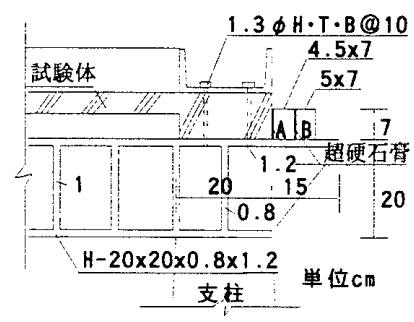

図ー3 拘束フレームの 寸法とスラブ支持状熊

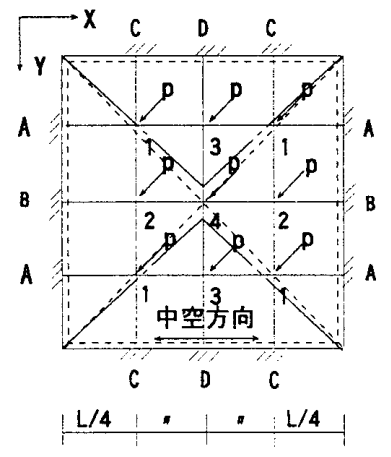

図-4 モデル化と破壤 機構
STLの次に，中空孔の直径，ハイホン，その後に，(A)部 分の補強鐝の本数を示して表している。シリーズ 1にの み, 同一の試験体を 2体用いているので,このことを示 すために，試験体名の最後に，1か 2を付けて表してい る。シリーズ 3 のングの数を 2 倍にした試験体の場合 は，(部分の補強鋼の本数に，X2を付けて表している。 鉄筇（直径 $3.2 \mathrm{~mm} ）$ は， $5 \mathrm{~cm}$ 間隔格子の溶接金網（図 ー1に点線で示している)である。尚, 弾性域における 二力向スパンの曲け劍性の差は偉かなため，二方向等量 配筋とした。

モルタル，鉄筋の力学的性質を表一1に記す。また，H 形、リングの降伏点, ヤング係数は，それぞれ $3100 \mathrm{~kg} \mathrm{f/}$ chl, $2.1 \times 10^{6} \mathrm{~kg} \mathrm{f} / \mathrm{cll}^{\circ}, 3000 \mathrm{~kg} \mathrm{f} / \mathrm{cm}^{2}, 2.1 \times 10^{6} \mathrm{~kg} \mathrm{f} / \mathrm{cul}^{2}$ である。 せん断補強鋼断面の中空孔（等断面の正方形に置換） 間のウエブ断面に対する割合を，表ー3に示す。

図一3は，支持部の回転と水平移動を拘束している陚 験体周辺の支持状態を示す。使用した拘束フレームは， 文献 8)で用いたと同じものであり，説明を省略する。

載荷は，図ー4に示すように，9点の集中荷重とする。

3. 実験結果

シリーズ 1〜3の中空スラブ試験体の，スラブ上, 下 面の亀裂，および破塓状況を図一5に示す。龟裂は細い

表一 1 材料の力学的特性

\begin{tabular}{|c|c|c|c|c|}
\hline \multirow{2}{*}{$\begin{array}{l}\text { シリ } \\
-x\end{array}$} & \multicolumn{2}{|c|}{ モルタル } & \multicolumn{2}{|c|}{ 鉄管 } \\
\hline & $\begin{array}{c}\text { 溞度 } \\
\mathrm{kgf} / \mathrm{cm}^{2}\end{array}$ & $\begin{array}{c}\mapsto ソ ク ゙ \text { 係数 } \\
\times 10^{5} \mathrm{kgf} / \mathrm{cm}^{2}\end{array}$ & $\begin{array}{l}\text { 降伬尔 } \\
\mathrm{kgf} / \mathrm{cm}^{2}\end{array}$ & $\begin{array}{c}\text { ヤング 係数 } \\
\times 10^{6} \mathrm{kgf} / \mathrm{cm}^{2}\end{array}$ \\
\hline \multirow[t]{2}{*}{1} & 297 & 1.80 & 3450 & 2.10 \\
\hline & 347 & 1.80 & 5530 & 2.00 \\
\hline 2 & 301 & 1.76 & 5980 & 2.10 \\
\hline 3 & 259 & 1.82 & 4310 & 2.10 \\
\hline
\end{tabular}

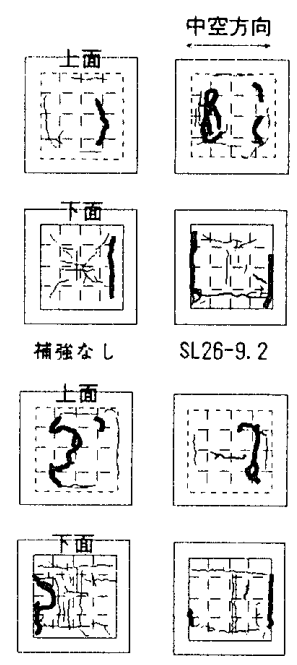

STL26-5.1 STL26-9.1

( a ) シリーズ 1

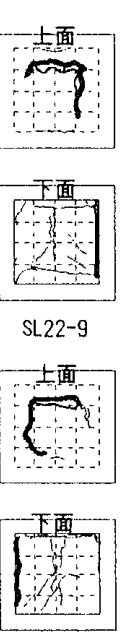

SL26-9
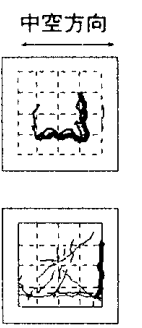

STL22-5
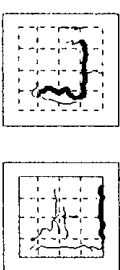

STL26-5
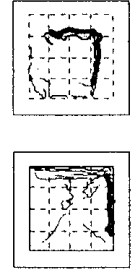

STL22-9
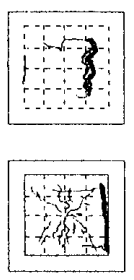

STL26-9

(b) シリーズ2
中空方向
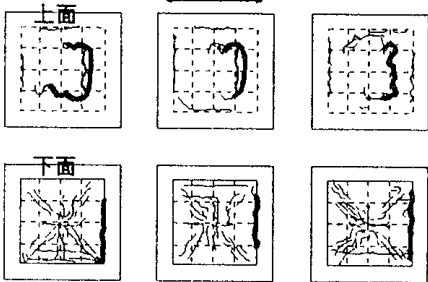

SL18-6

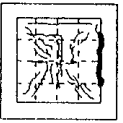

STL18-6

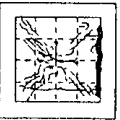

STL.18-12
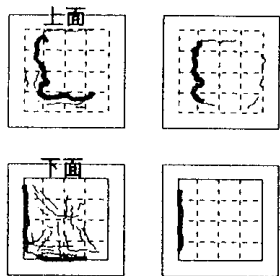

STL18-6X2 SL 18-0

(c) シリーズ 3

図一 5 龟裂と破壊図 
線で表現し，せん断で陥没破壊した所は，太い線で表し ている。

図-5 シリーズ 1では, 各スラブ 2体のうち 1体のみ を示す。SL26-9.2，STL26-9.1の破壊図により，“補 強なし”型よりも，中空方向の一方向性が,さらに顕著 になっているように観祭される。

同図シリーズ 2において, STL22-5，STL26-9では曲 げ亀裂が若干增えた程度で，全体的に，一方向性の特性 も残存している。

同図シリーズ 3においては, SL18ー0はせん断補強の 施していない試験体であり，中空方向の一方向性の破壊 を顕著に示している。この試験体以外は，スラプ下面対 角線上の曲げ亀裂が増加して，二方向性の傾向の強い破 壊型を示している。

図一6は，H形で補強したシリーズ 1の中筀スラブの破 壊進行状況を調べるために，スラフ上面の(1)(2)の位置を コンクリートカッターで切断して，観繁した断面内の破 壊状態を示したものである。

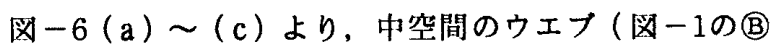
部分）の破壊状態が読み取れる。この図と，図一5(a) の(A)部分で，せん断で陥没破壊していることを重ね合わ せると、シリーズ 1 の破壊進行状況は，先にß部分のウ エブがせん断破壊した後，中空方向が一方向性のスラフ と化して，(A)部分で一気にせん断破罗したものと考えら れる。

さらにこの破壊進行状況を明らかにするために，ST L26-5.1のスラブ上下面の歪测定值（コンクリート王維 歪と鉄筋引張霆）を用い，断面の平面保持が成立すると 仮定して，中空方向おょび，中空方向に直角な方向の曲 率を、2箇所の平均で求めたのが図ー7である。9t付近 で，中空方向に直角な方向の曲率が急減して，中空方向 で急増している。これは，中空方向に值角な方向のウエ ブが先に破壊して，断面が上下 2層に分離した結果，曲 率が急減し，中空方向人の荷重負担が一気に增加したも
のである。シリーズ 2と 3 の, 中空方向および中空方 向に直角な方向の曲率については，シリーズ1ほどに， その変化が明瞭でないので，曲率図を省略した。

目ー14に，全試験体の荷重一たわみ曲線を，5章の曲 げ解析による荷重一たわみ曲線と共に揭げた。

尚, シリース 1の SL26-9.1については, 載荷途中の 事故で，奏験を中断している。ここでは，SL26-9.2のみ を示す。

\section{4. 中空スラブのせん断耐力の計算}

本報告で取り报う正方形中空スラブの破壊は，前記し たように，一方向性が顕著なシリーズ 1から，スラフ下 面の対角線上の曲げ㙇裂が增加して，二方向性の強める シリーズ 2, 3の破壊まで, 複雑な破壊形状を示す。

このような中空スラブの解析には，中空スラブを簡単 なモデルに置換して取り扱う方が, 破壊形状を捉え易い ように思われるので, 格子梁構造にモデル化して, 解析 を進めることとする。

X方向に中空方向を持つ正方形中空スラブを，图ー4 のように，X，Y方向とも，それぞれ4等分して格子梁に モデル化する。図ー4の 4等分割線を，A-A〜D-D部材と 称し，ᄂ/4幅の断面を集約している。この格子梁構造の9 箇所の交点のそれぞれに，荷重 Pが作用するとする。

以下の解析においては，X方向の部材をたて穴系，Y方 向部材をよこ穴系部材と名付ける。また，図ー1のB部 分のせん断破壊を，よこ穴系部材のせん断破壊（解析 に文献 7)を再揭して用いる)として取り扱い，(A)部 分のたて分系部材のせん断破壊と分けて解析する。

\section{1 よこ穴系部材のせん断耐力式}

文献 7)で示した，上こ穴系部材の3つの破壊パター ンを，図-8（a）〜（c）に再揭し，せん断酎力の計算を 行う。

\section{1 .1 Aタイプの破填}

図-8（a）に示すように，上下筋間の $45^{\circ}$ 方向の

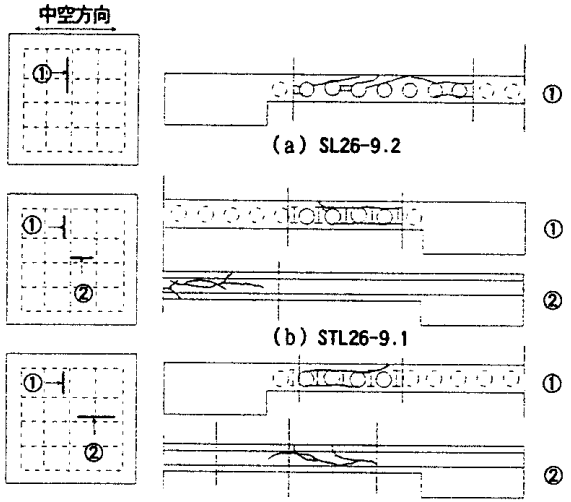

(c) STL26-5.1

図-6 シリーズ 1 の 断面の破壊状態

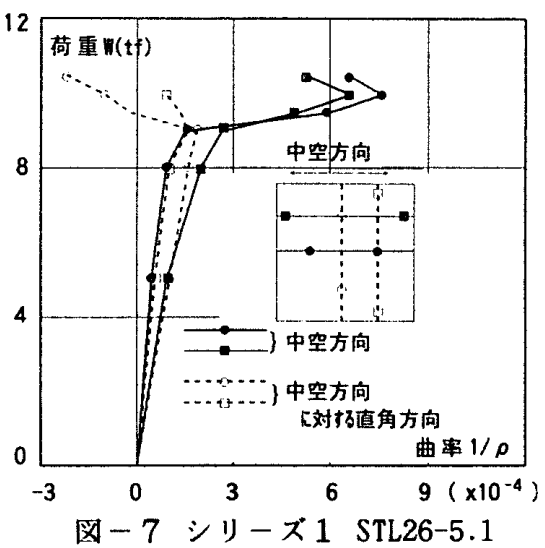

の荷重と曲率 


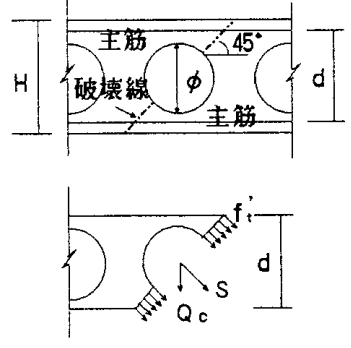

（a）Aパターンの破壊

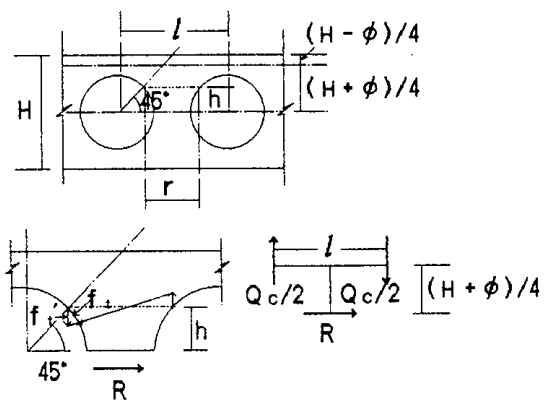

（b） Bパターンの破壊

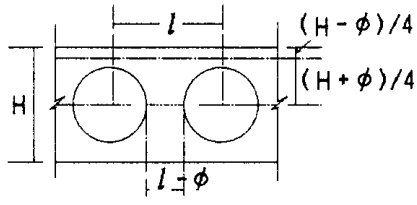

（c）Cパターンの破壊

図ー8 上こ穴系破壊パターン

断面に，斜め引張応力度 $\mathrm{f}_{\mathrm{t}}^{\prime}$ が生じるとして，せん断耐 力 $Q_{c}$ を得る。斜め引張力 $S$ は $S=(\sqrt{2} \mathrm{~d}-\phi) \mathrm{bf}_{\mathrm{t}}{ }^{\prime}$ で求まり，せん断耐力Qc は次式で与えられる。

$$
Q_{c}=S / \sqrt{2}=(\sqrt{2} \mathrm{~d}-\phi) \mathrm{bf}_{\mathrm{i}}{ }^{\prime} / \sqrt{2} \cdots(1)
$$

斜め引張応力度 $\mathrm{f}_{\mathrm{i}}^{\prime}$ は応力集中係数 $\mathrm{k}_{\mathrm{A}}$ を用いて, $\mathrm{f}_{\mathrm{t}}{ }^{\prime}=\mathrm{f}_{\mathrm{t}} / \mathrm{k}_{\mathrm{A}}$ から求める。 $\mathrm{f}_{\mathrm{t}}\left(\mathrm{f}_{\mathrm{t}}=0.39 \mathrm{~F}_{\mathrm{C}}{ }^{0.73}, \mathrm{~F}_{\mathrm{C}}\right.$ はモル タル強度) はモルタル引張応力度、 $\phi$ は円孔の直径, d は主筋上端から下端中心までの距離，bは部材幅であ る。 $\mathrm{k}_{\mathrm{A}}=2.1$ (この値の詳勫については，文献 7)で述 べている)を用いる。

\section{1 .2 Bタイプの破壊}

Bタイブは, 図-8（b)のように, ウエブに作用す るせん断力 $\mathrm{R} に よ っ て ， 45^{\circ}$ の扎䋑から曲げ篦を起こ し，水平方向に破壊するとする。フランジ部の断面で求 めるせん断耐力Q， は，曲げ亀裂が生じる時のウエブ水 平方向のせ九断力 $\mathrm{R}$ から得る。この $\mathrm{R}$ と $\mathrm{Q}$ 同関係と,

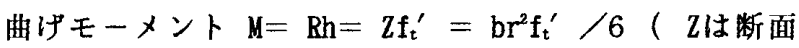
係数）より， $\mathrm{R}=\mathrm{br}^{2} \mathrm{f}_{\mathrm{t}}{ }^{\prime} / 6 \mathrm{~h}$ であるから，

$$
Q_{\mathrm{c}}=\mathrm{R}(\mathrm{H}+\phi) / 2 l=\frac{\mathrm{br}^{2}(\mathrm{H}+\phi)}{12 \mathrm{hl}} \mathrm{f}_{\mathrm{t}}^{\prime}
$$

を得る。ここで， $\mathrm{f}_{\mathrm{t}}{ }^{\prime}=\mathrm{f}_{\mathrm{t}} / \sqrt{2} ， \mathrm{r}$ は $45^{\circ}$ の孔緑位圆 のウエブ幅, $\mathrm{h}=\phi \sin 45^{\circ} / 2, l$ は中空孔ピッチ, Hは スラフ厚である。

\section{1 .3 Cタイプの破填}

Cタイブは，図ー8 (c) のように, 中空孔間のウエフ の最も狭い所で，水平せん断破壊を起こす場合である。 ウエブの水平方向のせん断力 $\mathrm{R}$ による平均せん断応力 度が, 斜め引張応力度 $\mathrm{f}_{\mathrm{t}}{ }^{\prime}$ になった時に破壊が生じる ものとする。中空孔間のウエブ幅が狭くなる時，大きな 応力集中を受けることから，応力集中係数 $\mathrm{k}_{\mathrm{c}}$ として， $\mathrm{f}_{\mathrm{t}}{ }^{\prime}=\mathrm{f}_{\mathrm{t}} / \mathrm{k}_{\mathrm{c}}$ を用いる。 $\mathbf{k}_{\mathrm{c}}$ の詳細は文献 7)で述べてお り, 次式によるものとする。

$$
\mathbf{k}_{\mathrm{C}}=10(1-/ / \mathrm{H})-10(0.7-\phi / \mathrm{H})+4
$$

Bタイプの破壊の項で得られたせん断耐力 Qc と，せん 断力 $\mathrm{R}$ の関係，および $\mathrm{R}=\mathrm{b}(l-\phi) \mathrm{f}_{\mathrm{t}}^{\prime}$ より，せん断

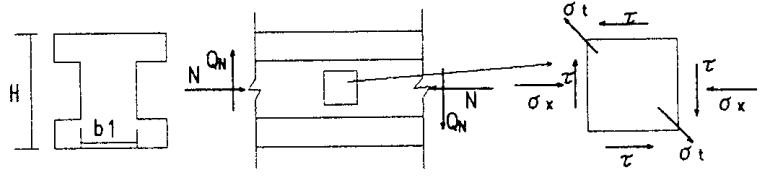

図ー9 たて穴系ウエブの忍力状態

耐力Qc は次式で得られる。

$$
Q_{c}=\frac{b(l-\phi)(H+\phi)}{2 l} f_{t}^{\prime}
$$

4. 2 たて穴系部材のせん断耐力式

計算を簡単にするために，図一9のように，中空孔を 等断面の正方形に置換した I形断面に, 圧縮面内力 $\mathrm{N}$ と せん断力 $Q_{N}$ が作用して，ウエブに斜め亀裂を起こす時 のせん断耐力 $Q_{N}$ を求める。ウエブ部分の応力状態から， 斜め方向に生じる引張応力 $\sigma$ 。 は次式で得られる。

$$
\sigma_{\mathrm{t}}=-\frac{\sigma_{\mathrm{x}}}{2}+\sqrt{\left(\frac{\sigma_{\mathrm{x}}}{2}\right)^{2}+\tau^{2}}
$$

$\tau=S_{\mathrm{n}} \mathrm{Q}_{\mathrm{N}} / \mathrm{I}_{\mathrm{n}} \mathrm{bl}, \sigma_{\mathrm{x}}=\mathrm{N} / \mathrm{A}_{\mathrm{c}}$ で, $\mathrm{S}_{\mathrm{n}}, \mathrm{I}_{\mathrm{n}}$ はウエフ断面中心 軸に関する断面 1次と 2次モーメント， $A_{C}$ は I形の断 面皘、b1はウエブ幅である。せん断力 $Q_{N}$ を求めると

$$
Q_{\mathrm{N}}=\frac{\mathrm{I}_{\mathrm{n}} \mathrm{b} 1}{S_{\mathrm{n}}} \sqrt{\sigma_{\mathrm{t}}{ }^{2}+\sigma_{\mathrm{t}} \frac{\mathrm{N}}{\mathrm{A}_{\mathrm{C}}}}
$$

を得る。（6）式より， $\sigma_{t}=f_{t}$ としてせん断酎力 $Q_{N} を$ 求める。

4. 3 中空スラプの全せん断耐力

図ー8に示した，よこ穴系部材破壊パターンA〜Cタ イプの計算を, 部材幅 $25 \mathrm{~cm}$ で求めたのが表一2の值であ る。A〜Cタイプの最小值（*印の值）で，ょこ穴系部 材のせん断耐力が決定される。ただし，Cタイプで決定 される場合，よこ穴系中空スラブ断面は2層に分離した 状態となり，曲げで抵抗するものとする。

表一2の值から，よこ穴系部材の全負担せん断酎力を 求め、これをよこ穴系耐力 Qyとして表一3に示している。 表ー3にはまた，(6) 式を用いて計算した中空方向部材 の全負担せん断酎力を，たて穴系酎力 Qxとして示して いる。たて穴系部材の耐力算定には，壬縮面内力の影鳌 を考慮している。よこ穴系耐力とたて穴系耐力を合計し 

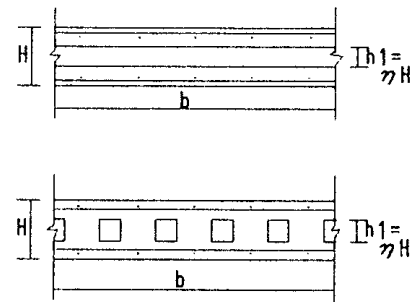

図ー10よこ穴，たて穴

部材断面

て，中空スラブのせん断破壊酎力

Ws（全せん断耐力と

称す）を求めた。

表一3のよこ穴系酎力に，一那が記されている筒所は， よこ穴系部材の中空断面が，2層に分離すると考える場 合であり，下記の方法で全せん断耐力を求めている。

予め，スラブ荷重 9tが作用した時の，よこ穴系の全 負担せん断力 $\mathbb{H}_{Y}$ ，後記する（9）式のたて穴系部材の 断面 2次モーメントと，2層に分離した（7）式のよこ 穴系部材の断面 2次モーメントを用いて求める。次に， 貼から，スラブ荷重 $W_{S}$ （全せん断耐力）が作用する 時の, よこ穴系の全負担せん断力 $\mathrm{wQ}_{\mathrm{y}}$ を， $\mathrm{w}_{\mathrm{Y}}=\mathbb{W}_{\mathrm{S}} \frac{\mathbb{W}_{\mathrm{Y}}}{9}$ で得る。この值と，表一3のたて穴系の全負担せん断耐 力 $Q_{\mathrm{x}}$ の和である $W_{\mathrm{s}}=Q_{\mathrm{x}}+{ }_{\mathrm{w}} Q_{\mathrm{y}}$ に, 前記 $\mathrm{w}_{\mathrm{y}}$ の值を代入し て，全せん断耐力 $\mathbb{T}_{\mathrm{s}}$ を(8) 式に導き，計算する。

$$
\begin{array}{ll}
\mathrm{I}_{\mathrm{Y}}=\mathrm{bH}^{3}(1-\eta)^{3} / 48 & \cdots \\
\mathrm{W}_{\mathrm{S}}=\frac{90_{\mathrm{x}}}{9-\mathrm{W}_{\mathrm{Y}}} & \cdots \cdot(7)
\end{array}
$$

表ー2，3には，シリーズ 1に“補強なし”型を加え て比較に供している。

\section{5.曲げによる荷重とたわみの算出}

曲げによる計算は，文献 8）の基本仮定と算出方法を 用いて行う。ただし，中空スラブは直交異方性で，図一 4のように，対角線からずれた降伏線（例えば，シリ一 ズ 1 の試験体の場合，対角線より 1 ずれる）を示すが, 計算を簡単にするために，降伏線は対角線とする。

中空孔を等断面の正方形に置換した，X方向のたて方 系部材と，Y方向のよこ穴系部材断面を，図一10のよう に表し，計算に必要な部材の曲げ剛性，ねじり剛性を求 める。

無亀裂の場合のたて穴，よこ穴系部材の断面2次モ一 メント $\mathrm{I}_{\mathbf{X}} \mathrm{I}_{\mathrm{Y}}$ は, 次式で与えられる。

$\mathrm{I}_{\mathrm{X}}=\mathrm{H}^{3}\left(\mathrm{~b}-\mathrm{m} \eta^{4}\right) / 12, \mathrm{I}_{\mathrm{Y}}=\mathrm{bH}^{3}\left(1-\eta^{3}\right) / 12 \quad \cdots(9)$

ここで, $\eta=\mathrm{h} 1 / \mathrm{H}, \mathrm{h} 1$ は正方形断面の 1 辺, 部材幅 $\mathrm{b}=$ $\mathrm{L} / 4$ で，b幅当たりの中空孔の数 $\mathrm{m}=\mathrm{b} / \mathrm{H}$ である。

たて穴，よこ穴系部材のねじり㓮性は，断面のねじり 定数 $\mathrm{J}_{\mathrm{P}}=\alpha \mathrm{bH}^{3}$ （ $\alpha$ は部材断面による係数）と，有効せ
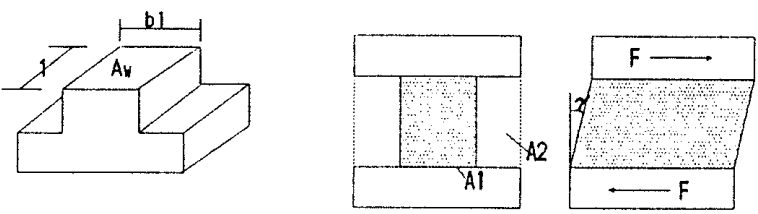

眓ー12よこ穴部材のねじり変形 のねじり変形

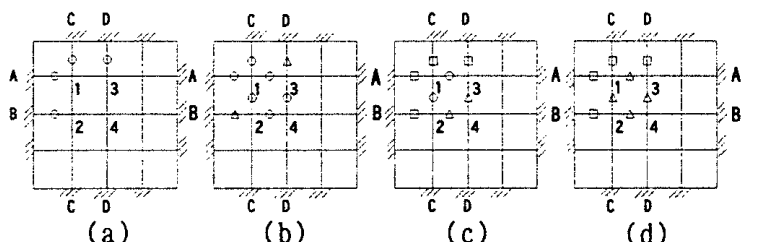

図-13 亀裂進行状態

ん断砗性係数 $\mathrm{G}_{\mathrm{X}} ， \mathrm{G}_{\mathrm{Y}}$ を用いて，それぞれ $\mathrm{G}_{\mathrm{X}} \mathrm{J}_{\mathrm{p}} ， \mathrm{G}_{\mathrm{y}} \mathrm{J}_{\mathrm{p}}$ で 表す。たて穴系部材の有奻せん断弾性係数 $G_{x}$ は, 次式 のように，図ー11のフランジに，Fが作用した時の変位 $\delta_{\mathrm{H}}$ から得た平均せん断歪 $\gamma$ と, 平均せん断応力度 $\tau=\mathrm{F} / \mathrm{A}_{\mathbf{w}}$ から求める。

$$
\begin{gathered}
r=\frac{\delta_{\mathrm{H}}}{\mathrm{h} 1}=\left(\frac{h 1^{2}}{12 \mathrm{E} \mathrm{I}_{\mathrm{W}}}+\frac{\kappa}{\mathrm{GAW}}\right) \mathrm{F} \\
\mathrm{G}_{\mathrm{X}}=\frac{\tau}{r}=\frac{\mathrm{E}}{\frac{\eta^{2}}{(1-\eta)^{2}}+\frac{\mathrm{E} \kappa}{\mathrm{G}}}
\end{gathered}
$$

ここに，b1をウエブ幅として， $\mathrm{I}_{\mathrm{w}}=\mathrm{b} 1^{3} / 12, \mathrm{~A}_{\mathrm{w}}=1 \mathrm{xbl}$ （図 -11)である。 $\kappa=1.5, \mathrm{E}$ はルタルのヤング係数であ る。

また，よこ穴系部材の有奻せん断弾性係数 Gy は，図 ー12に示すように, せん断弾性係数 Gが, ウエブを有す る領域の全断面積 $A_{2}$ 時に有効で, ウエフ断面 $A_{1}$ に比例 するとして，次式となる。

$$
\mathrm{G}_{\mathrm{Y}}=\mathrm{GA}_{1} / \mathrm{A}_{2}=\mathrm{G}(1-\eta)
$$

刍裂発生後の部材の曲げ㴊性 $\mathrm{EI}_{\mathrm{B}}$ の取り报いは，亀

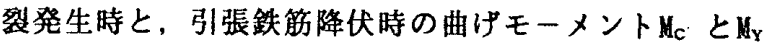
の中間值 $M_{\mathrm{A}}=\left(M_{\mathrm{C}}+\mathrm{M}_{\mathrm{Y}}\right) / 2$ の值を用い, 次式 (13)の $\lambda$ を得て， $\mathrm{I}_{\mathrm{E}}=\lambda \mathrm{I}_{\mathrm{G}}$ と表して算出する。

$$
1 / \lambda=1+\left(K_{0} / K_{Y}-1\right)\left(1-M_{C} / K_{A}\right) /\left(1-M_{C} / M_{Y}\right)
$$

$\mathrm{K}_{\mathrm{O}}=\mathrm{E} \mathrm{I}_{\mathrm{G}}$ で， $\mathrm{I}_{\mathrm{G}}$ は無㙇裂時の断面 2次モーメント， $\mathrm{K}_{\mathrm{Y}}$ $=E I_{c}$ で, Ic は釷裂時の断面 2次モーメントである。 Icはモルタルの引張応力度を無視し, 圧縮応力度を直 線分布として求めている。

さらに，置換部材の曲げ甽珄は，雨端の急裂状況に応

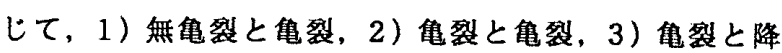
伏に分類し，それぞれの平均値を採る。

図ー13に，その部材の龟裂と降伏箇所が広がってい 
〈順序を，前記㿝裂状況 1)，2〉，3）順に， $， \triangle$, 口抱で示す。

また，部材の亀裂によるねじり唧性の低下の割合は， 曲げ剛性の低下の割合と同じであると仮定する。
Johansen荷重以後の荷重たわみの算出については，曲 げによるスラブ荷重 $W_{M}$ が, 次式と変わる以外, 文献 8) と同じであり，制愛する。

$$
W_{M}=9 p=\frac{32}{5 L}\left(2 M_{\mathrm{A}}+2_{x} M_{1}+{ }_{x} M_{B}+{ }_{x} M_{4}+2{ }_{y} M_{C}\right.
$$
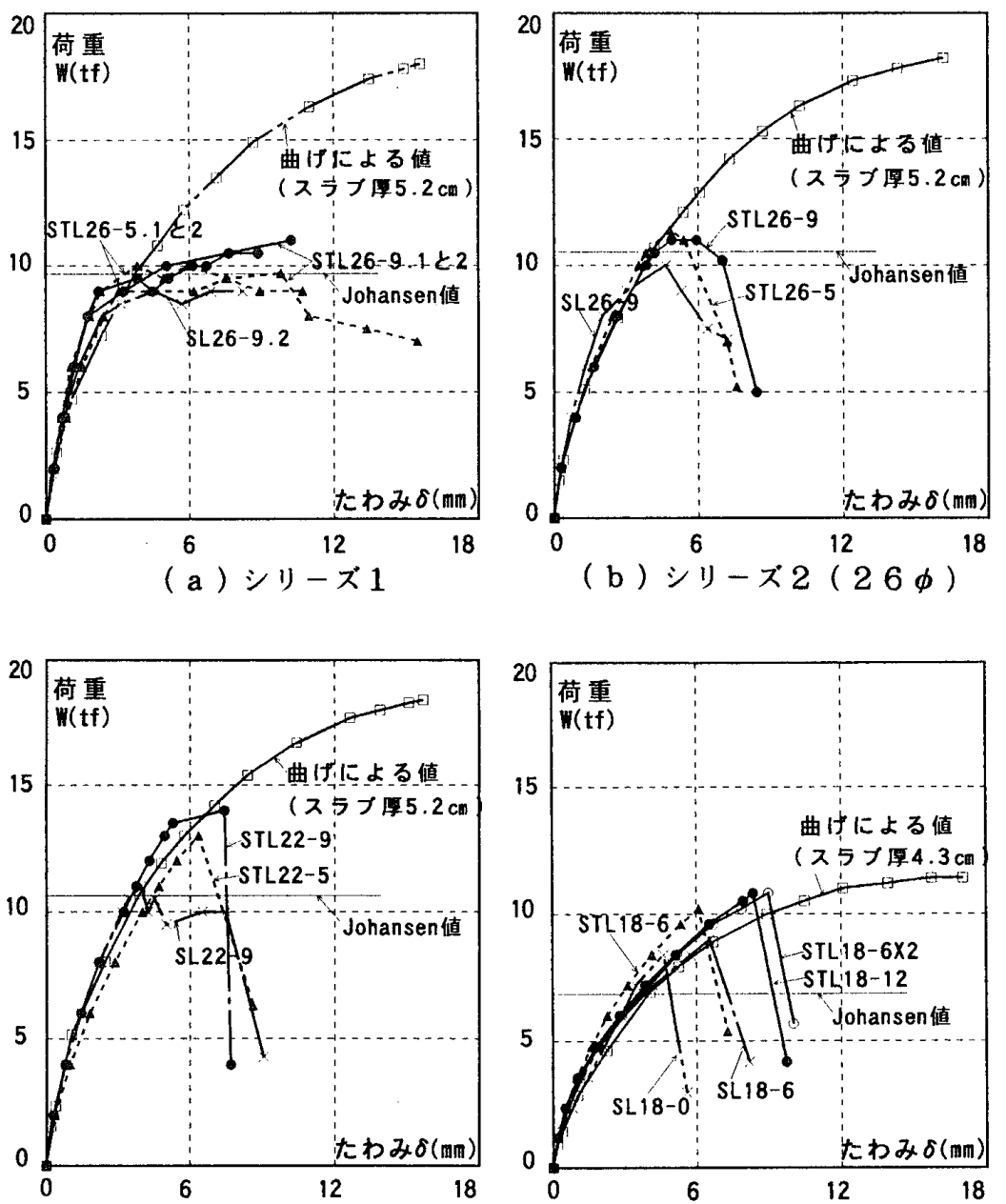

(c) シリーズ2(22ф)

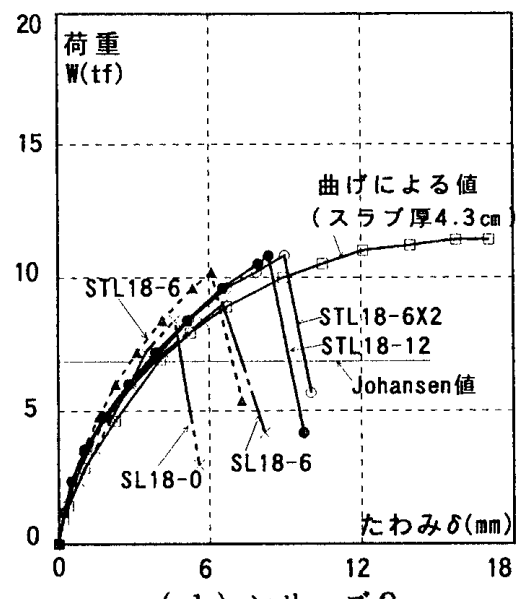

(d) シリーズ 3

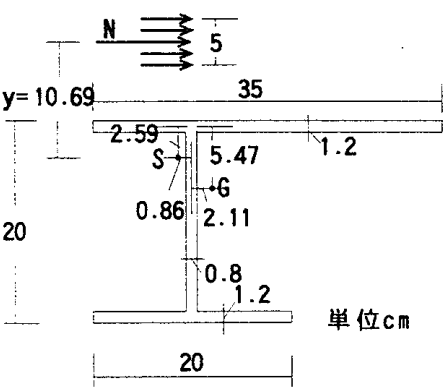

因一 15 拘束フレームに作用

する圧穛面内力とその位置

表ー2よこ穴系部材のせん断耐力

\begin{tabular}{|c|c|c|c|c|c|}
\hline \multirow[t]{2}{*}{$\begin{array}{l}シ リ \\
-ス ゙\end{array}$} & \multirow{2}{*}{$\begin{array}{l}\text { 円扎 } \\
\text { 径 } \\
\phi\end{array}$} & \multirow{2}{*}{$\begin{array}{l}\text { スラ } \\
\text { プ厚 } \\
\mathrm{H}(\mathrm{cm})\end{array}$} & \multicolumn{3}{|c|}{ 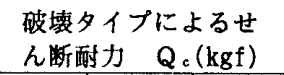 } \\
\hline & & & A & B & C \\
\hline \multirow{3}{*}{1} & \multirow{3}{*}{$26 \phi$} & 5.0 & $492 *$ & 606 & 516 \\
\hline & & 5.1 & 586 & 688 & $563 *$ \\
\hline & & 5.2 & 619 & 697 & $549 *$ \\
\hline \multirow{5}{*}{2} & \multirow{3}{*}{$22 \phi$} & 5.0 & $583 *$ & 810 & 904 \\
\hline & & 5.2 & $643 *$ & 832 & 803 \\
\hline & & 5.3 & $673 *$ & 844 & 766 \\
\hline & \multirow[t]{2}{*}{$26 \phi$} & 5.0 & $498 *$ & 611 & 520 \\
\hline & & 5.2 & 558 & 627 & $494 *$ \\
\hline \multirow{3}{*}{3} & \multirow{3}{*}{$18 \phi$} & 4.2 & $382 *$ & 586 & 527 \\
\hline & & 4.3 & $409 *$ & 592 & 502 \\
\hline & & 4.4 & $435 *$ & 602 & 480 \\
\hline
\end{tabular}

注:シリース 1最上段は“補強なし”型の 値を示す

図一 14 荷重一たわみ曲線

表 - 3 せん断耐力の実驗值と計算值の比較

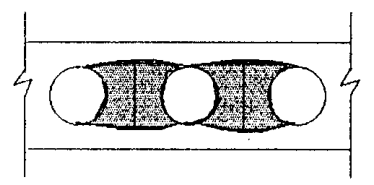

図-16 シリーズ1よこ 穴系の破壊

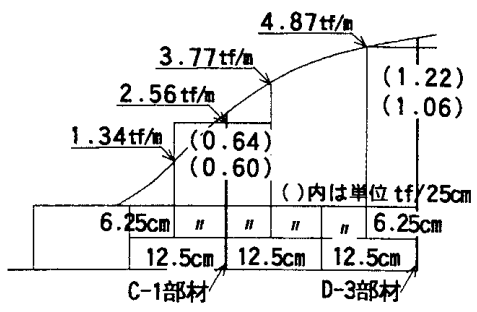

図 -17 精算值と略算值

\begin{tabular}{|c|c|c|c|c|c|c|c|c|c|c|}
\hline \multirow[b]{2}{*}{$\begin{array}{l}\text { シリ } \\
\text { ーズ }\end{array}$} & \multirow[b]{2}{*}{ 試験体 } & \multirow[b]{2}{*}{$\begin{array}{c}\text { スラ } \\
\text { ブ厚 } \\
\\
\mathrm{H} \\
(\mathrm{cm})\end{array}$} & \multirow[b]{2}{*}{$\begin{array}{c}\text { せん } \\
\text { 断補 } \\
\text { 強比 } \\
\text { Ps } \\
(\%)\end{array}$} & \multicolumn{3}{|c|}{ 実験値 } & \multicolumn{3}{|c|}{ せん断耐力計算值 } & \multirow{2}{*}{$\begin{array}{l}\text { 実/計 } \\
\frac{W_{E}}{W_{S}}\end{array}$} \\
\hline & & & & $\begin{array}{c}\text { せん夥 } \\
\text { 耐力 } \\
W_{E} \\
(t f)\end{array}$ & $\underset{(\mathrm{mm})}{\delta}$ & $\begin{array}{c}\text { 压縮面 } \\
\text { 内力 } N \\
\frac{\mathrm{kgf}}{\mathrm{cm}}\end{array}$ & $\begin{array}{c}\text { 上こ穴 } \\
\text { 系耐力 } \\
Q_{Y} \\
(\mathrm{tf})\end{array}$ & $\begin{array}{c}\text { たて穴 } \\
\text { 系酎力 } \\
Q_{x} \\
(\mathrm{tf})\end{array}$ & $\begin{array}{c}\text { 全せん } \\
\text { 酎力 } \\
W_{s} \\
\text { (tf) }\end{array}$ & \\
\hline \multirow{6}{*}{$\begin{array}{c}\text { シリ } \\
- \text { ズ } \\
1\end{array}$} & 補強なし & 5.0 & 0.0 & 8.0 & 2.5 & - & 3.0 & 7.1 & 10.1 & 0.79 \\
\hline & SL26-9.2 & 5.1 & 3.70 & 9.0 & 8.2 & - & - & 8.1 & 9.1 & 0.99 \\
\hline & STL26-5.1 & 5.2 & 3.70 & 10.5 & 8.8 & - & - & 8.3 & 9.2 & 1.14 \\
\hline & STL26-5.2 & 5.2 & 3.70 & 10.0 & 5.9 & - & - & 8.3 & 9.2 & 1.09 \\
\hline & STL26-9.1 & 5.2 & 3.70 & 11.0 & 10.2 & - & - & 8.3 & 9.2 & 1.20 \\
\hline & STL26-9.2 & 5.1 & 3.70 & 9.7 & 9.8 & - & $\begin{array}{ll}- \\
-\end{array}$ & 8.1 & 9.1 & 1.07 \\
\hline \multirow{6}{*}{$\begin{array}{c}\text { シリ } \\
- \text { - } \\
2\end{array}$} & SL22-9 & 5.0 & 1.04 & 11.0 & 3.9 & 40.9 & 3.5 & 9.6 & 13.1 & 0.84 \\
\hline & STL22-5 & 5.3 & 0.52 & 13.0 & 6.4 & 90.3 & 4.0 & 11.3 & 15.3 & 0.85 \\
\hline & STL22-9 & 5.2 & 1.04 & 13.5 & 7.4 & 80.0 & 3.9 & 10.8 & 14.7 & 0.92 \\
\hline & SL26-9 & 5.2 & 1.18 & 10.0 & 4.6 & 31.0 & - & 8.5 & 9.5 & 1.05 \\
\hline & STL26-5 & 5.0 & 0.59 & 11.4 & 4.8 & 36.1 & 3.0 & 8.4 & 11.4 & 1.00 \\
\hline & STL26-9 & 5.0 & 1.18 & 11.0 & 5.9 & 36.1 & 3.0 & 8.4 & 11.4 & 0.96 \\
\hline \multirow{5}{*}{$\begin{array}{c}\text { シリ } \\
- \text {-ズ } \\
3\end{array}$} & SL18-0 & 4.2 & 0.0 & 8.4 & 4.6 & 38.7 & 2.3 & 7.2 & 9.5 & 0.88 \\
\hline & SL18-6 & 4.2 & 0.23 & 9.0 & 6.6 & 41.5 & 2.3 & 7.2 & 9.5 & 0.95 \\
\hline & STL18-6 & 4.4 & 0.23 & 10.2 & 6.1 & 63.6 & 2.6 & 8.1 & 10.7 & 0.95 \\
\hline & STL18-12 & 4.3 & 0.46 & 10.8 & 8.4 & 63.6 & 2.5 & 8.0 & 10.5 & 1.03 \\
\hline & STL18-6X2 & 4.2 & 0.46 & 10.8 & 9.0 & 102.4 & 2.3 & 8.9 & 11.2 & 0.96 \\
\hline
\end{tabular}




$$
\left.+2 \mathrm{y}_{\mathrm{y}} \mathrm{M}_{1}+{ }_{\mathrm{y}} \mathrm{M}_{\mathrm{D}}+{ }_{\mathrm{y}} \mathrm{M}_{4}+2 \mathrm{x}_{\mathrm{x}} \mathrm{T}_{1}+2 \mathrm{y}_{\mathrm{y}} \mathrm{T}_{1}\right)-\sum \mathrm{M} \cdot \cdot(14)
$$
添字 $\mathbf{x}, \mathbf{y}$ は部材の方向を, 他の添え字は位置を示す。 $\sum \mathrm{M}$ は，圧縮面内力による付加モーメントの各部材の総 和である。計算結果を図ー14に，Johansen值と共に示す。

4.2節の，たて穴系部材のせん断酎力算定式に用 いる圧縮面内力 $\mathrm{N}$, Johansen荷重以後の曲げ解析に使 用する拘束フレームの拘束度 $\mathrm{k}$ 算出は，下記に示す值 を用いている。

図ー15に示す $\mathrm{y}$ の值は，拘束フレームのせん断中心 $S$ から、スラブ厚中心までの距離である。yの值はスラブ 懕設計值 $5 \mathrm{~cm}$ の時, $10.69 \mathrm{~cm}, 4.1 \mathrm{~cm}$ の時, $10.24 \mathrm{~cm}$ で り，両スラブ鲟について，スラフ周边中央部のそれぞれ の水平移動量は, $\mathrm{F} \delta=3.877 \times 10^{-6} \mathrm{~N}$ (この值は文献 8 )

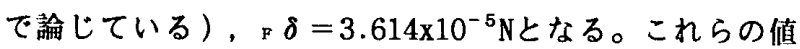
から，峏者の拘束フレームの拘束度 $\mathrm{k} は ， そ れ そ ゙ れ ， \mathrm{k}$ $=3.887 \times 10^{-5} \times 2 \mathrm{EA} / \mathrm{L}$ と $\mathrm{k}=3.614 \times 10^{-5} \times 2 \mathrm{EA} / \mathrm{L}$ を得る。 この計算において，Aと Nは，スラブ边の幅 1⿴囗十当たりの 断面積と圧縮面内力で，よこ穴系とたて穴系を区別して 用いている。また，モルタルのヤンク係数 Eは，弾性時 と同じとする。

\section{6. 実験結果と解析結果の比較と考察}

表ー2に揭げた，図一1のß部分（図-4のC-1，D-3 部材）における A， B， C夕イプのせん断耐力は，せん 断補強を無視して求めた，置換部材 $(25 \mathrm{~cm}$ 幅) 当たりの 計算值で，3者の内の最小值に*明を付けて示している。 破壊タイプはAかCかであり，Cタイプで破壊している 場合は，その部材が 2㒶に分離した状熊にあると考え， スラブの全せん断耐力を求めている。

この表 -2 , A夕イフの值を 6倍して, 表-3のよこ 公系酎力の籍に記している。また，Cタイプの場合は 一用を付けている。

さらに（®部分のせん断酎力を，圧縮面内力（表-3 に併記している）を考虑して，6つの部材酎力を合計し， たて穴系酎力として求めた。両者の合計がスラブの全 せん断耐力である。計算に用いた圧縮面内力の值は, 前 記スラブ周辺中央部の害験時の水平移動量 $\mathrm{F} \delta$ を用いて 得ている。この実験時の圧繀面内力は, 現在適切な推定 方法が兒あたらないため，使用したものである。

表一3の值より，“補強なし”の場合と同断面の試験 体の全せん断力が, 単純にモルタル強度に比例するとし て比較すれば, シリーズ 1 の SL型で同程度, STL型で 2

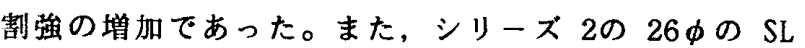
型では 2割強、STL型では 4割の増加であった。これら 耐力の增加は, (B)部分の補強奻果や、リンクの補強奻 果の影響である。さらに，シリーズ 2の中空孔の大き

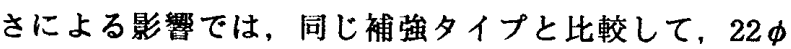

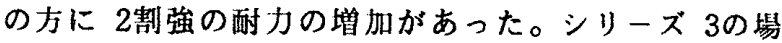
合，無䋠強のSL18-0と，(A)部分のみにせん断補強を施 した SL18ー6を比較すれば，SL18-6の耐力堌は 1制郡 程度しか得られていないが，(B)部分にもせん断補強した STL18ー6と，SL18一0を比較すると，STL18-6に 2割の 耐力增が見られる。さらに，(1)部分の補強を增加する時 (STL18-12，STL18-6X2），3割程度まで，耐力が增加 する。

次に，実験值と計算值の比較では，シリーズ 1の埸合 は，実験值の方が大きく，シリーズ 2,3では計算值の 方が大きい。このとは、シリーズ 1 と $2,3 の$ 同部分 の破壊形状の違いと、シリーズ 1の計算值に，玨竦面内 力を考慮していないことと，後記する略算值のよこ穴 部材の支持反力が, 精算值より小さめに得られているこ とによると思われる。シリーズ 2，3において，(®と 部分が，同時に破壊するとして計算した結果は、郡算俌

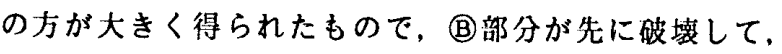
続いて，(A)部分の破壊が起こる 1つの根拠を与えている と考察する。

表一3より，よこ穴系とたて分系耐力を比較すると， シリーズ 1では，よこ穴系耐力がたて公系のほは 1/8程 度，シリーズ 2，3では，ほほ1/3程度となつており， よこ穴系酎力が粫めて小さく，前記した同部分の先行破 壊の原因に挙げられよう。

次に，奏験による中空スラブの荷重一たわみ曲線を， 曲け解析值と併記して，図ー14（a)〜（d）に示した。 シリーズ 1では，“補強なし”型を加えて比較に供し， 全せん断耐力とたわみの関係を検討する。

図ー14（a）シリーズ 1に見られるように，荷重增加 が得られないまま，たわみが増加している。これは(B)部 分の断面が 2層に分離して, 曲げで抵抗し, (4)部分のH 形補強銅が，その部分のせん断破壊を通らせている状況 を示している。

図ー16は，H形で補強したシリーズ 1 のB部分の破壊 断面を拡大したもので，形を包むようなBタイプの破 壊形状を示しており，2層分離がより顕著になったもの と判断する。

曲げ破壊に近ずくように意网したリングの效果につい ては, シリーズ $2(26 \phi)$ と, 形で補強したシリーズ と比較して，若干の酎力增は見られたものの，䩗性に 関しては，大きな効果はみられない。

シリーズ $2(22 \phi)$ では, SL形と STL形の破壊時の耐 力差に, リングのせん断補強奻果が比較的はっきり表れ ているが，曲げ耐力より 3 割弱小さく，たわみも曲げの 半分程度て，26ф同様靱性のそしいスラブであった。

スラプ曆を薄くして，ょり曲げ破壊への指向性を強め たシリーズ 3の全せん断酎力は，曲げ酎力（Johansen値 
の約1.5倍）とほほ同じ程度に得られているが，たわみ は曲げの場合の半分程度で，脆性的破壊を示している。

以上，当試験体に施したせん断補強㱛果と，靶性的側 面から，実験結果を捉えるために，曲げ解析にもとすい て実験値との此較を行った。計算による荷重一たわみ曲 線は，実験結果とよく追随しておりこの曲げ解析から すれば，(B)部分および(部分に対する補強効果は見られ るものの，勒性のそしいスラブであると言える。

このことの第一の要因は，B部分のせん断破壊が先行 して起こるためと考える。

図ー17は，シリーズ 1の“補強なし”型を対象に，9 点載荷（各点 $1 \mathrm{tf}$ 載荷）時の $\mathrm{C}-1, \mathrm{D}-3$ 部材の支持反力 の精算值（文献 13)ょり求めている）と，格子梁直换に よる略算值とを比較したものである。精算值は稫 $25 \mathrm{~cm}$ で分割した時の阿端から，1／4内側における幅 $1 \mathrm{~m}$ 当た りの支持反力の平均伯である。幅 $25 \mathrm{~cm}$ の合支持反力を （）内に示した。（）内の上段は精算值，下段が略算值 である。D-3部材は，精算估が略算值と比較して $15 \%$ 增 で，C-1部材は $4 \%$ 增である。精算㒹が大きく得られる

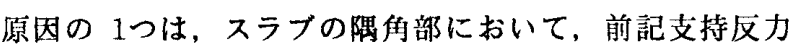
の逆方向の力が生じるためと考える。

これら精算值と略算值を、D-3部材と 2 本の C-1部材 の3部材で平均すれば，精算值は略算値の $8 \%$ 增で得ら れる。このことぶ, 表ー3シリーズ 1 の全せん断酎力計 算值を，奏験值より小さく算出する一因であろうと思わ れる。

以上，当中空スラブの複雑なせん断破壊形状，および せん断丽力についての考察を，せん断と曲げ解析を媒介 として行った。その結果, かなり具体的に諸現象を解明 し得たと考える。尚, 奏験結果において, せん断補強銅 による酎力增加が大きなものでなかったこと，また，複 雑で脆㭫的なせん断破壊形状を示すあのであったことな とから、この破壊現象を大局的に捉えることが大切と考 えて，せん断補強鎆による効果をせん断解析から省略し ている。また，よこ穴系部材とシリーズ1について，圧 縮面内力を省いた根挑は, 前記したようにせん断耐力が 極めて小さいことや，早期せん断破壊のために，耐力增 加かほとんど得られていないためである。

\section{7. 結語}

以上，せん断による早期破壊を防止するために， H形 またはリング鋼で補強した，3種類の正方形中空スラブ の載荷実験を行い，それぞれのせん断破壊形状，終局酎 力, たわみの伸展状況等について, 理論值との対応を検 討した。その結果，ょこ穴系部材のせん断耐力は極めて 小さく，よこ穴系部材に先行破堿を生じさせるものであ

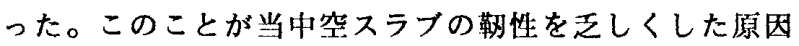
であろう。これらのことから，上こ穴系部材のせん断酎
力を高めることが, 当中空床スラフの曲げ破壊を可能に する方策と考える。

本報告の格子梁置換によるせん断酎力解析は，奏験結 果を良く追跡するものであり，また，試験体の全せん断 耐力やたわみの検討に当たり，曲け解析結果を比較，対 照することによつて，妥当な判断を与えるものであった と考える。

今後はせん断補強鋼の影餐について，さらに迫 究を深めたい。

謝辞

終始ご指筫を頂いています北海道大学士橋由造 名誉教授，ならびに，当実験において多大の協力 を得ましたぜ生に感謝の意を表します。

\section{参考文献}

1）松井源吾：中空スラフと構造計画、建策文化，Vol.19,№.216, pp.133-140,1964.10

2) F.Simons:Vierseitig gelagerte Stahlbetonhohlplatten mit gleichma iger Belastung, Die Bautechnik, Vol.42,No.7,pp.23 $7-241,1965.7$

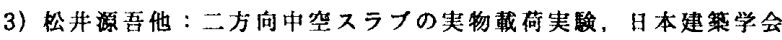
大会学術溝演梗概集, pp.1461-1462,1980.9

4）松并源吾：中空スラフの計画と設計，鹿島出版会，pp.33-35， 1988.6

5）入江善久他：ボイドスラフのせん断强度に閭する実駼的研究 (その1) 正方形スラブについての予借実験, 日本建築学会大 会学術講演梗概集，pp.635-636,1994.9

6）入江善久他：周辺支持ボイドスラブのせん断抵抗に関する実鋻 的研究一（その 2$)$ 值交市方向のせん断酎力について一，日本 建策学会大会学術渾演梗概集，pp.639-640,1995.8

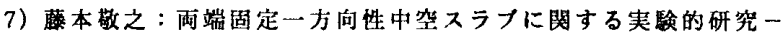
（その2）中空スラフのれと直交方向のせん断破俵について一， 日本建築学会楼造系薢文集, pp.123-129,1994.6

8）藤本敬之：铁筇コンクリート正方形スラフの酎カとたわみに関 する研究，日本建筑学会構造系諭文集，pp.89-96,1993.5

9）藤本敬之：正方形中空スラフのせん断破堘に関する実驗的研究 （その1），日本建築学会中国支部研究報告集，pp.125-128，198 9.3

10）藤本敬之：正方形中空スラフのせん断破烄に関する穾駼的研究 (その2)，日本建筑学会大会学術講演梗概集，pp.287-288,198 9.10

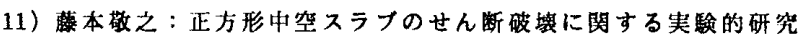

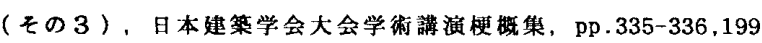
1.9

12）藤本敬之他：両端固定一方向性中空スラフル関する実駼的研究， 日本建策学会棰造系就文集,pp.52-60,1985.11

13）坪井善腾：連綍体力学序説，座業図菖，pp.86-91，1977.10

（1995年12月19日原稿受理，1996年 7 月29日採成決定） 